\author{
KAROL MODZELEWSKI \\ Instytut Historyczny Uniwersytetu Warszawskiego \\ Professor em.
}

\title{
KTO POSTRZYGŁ SIEMOWITA? SŁOWIAŃSCY DIOSKUROWIE W MICIE DYNASTYCZNYM PIASTÓW
}

\begin{abstract}
Abstrakt: Na porównawczym tle średniowiecznych mitów początku rozmaitych ludów średniowiecznej Europy autor przeprowadza analizę mitu dynastycznego Piastów. Analiza ta prowadzi do wniosku, że dwaj tajemniczy przybysze, którzy w chacie Piasta dokonali cudownego rozmnożenia piwa i wieprzowiny, a następnie postrzygli syna Piasta, nadali mu imię Siemowit (pan rodu) i przez ten obrzęd usynowili pierwszego władcę Polan oraz całą piastowską dynastię - byli słowiańską odmianą dioskurycznych boskich bliźniąt.
\end{abstract}

Słowa kluczowe: mit dynastyczny Piastów, religia pogańska, Słowianie, słowiańscy dioskurowie, Aświnowie, transfer kulturowy.
Abstract: Against a comparative background of medieval myths of the origins of peoples in medieval Europe, the author performs an analysis of the dynastic myth of the Piasts. The analysis leads him to the conclusion that two mysterious strangers who in Piast's hut performed a miraculous multiplication of beer and pork, and then a ritual cutting of hair of Piast's son whom they named Siemowit (meaning the ruler or master of the family) and through this ceremony took him as their own son thus establishing a special link between themselves and the whole Piasts' dynasty - were a Slavonic version of the divine twin brothers, the Dioscuri.

Keywords: dynastic myth of the Piasts, pagan religion, Slavs, Slavonic Dioscuri, Ashvins, transfer of culture.

Archaiczne kultury barbarzyńskiej Europy miały wyraziste rysy patriarchalne. Dotyczy to nie tylko struktur pokrewieństwa, ale i struktur politycznych. Plemienny król (książę) był wyposażony w atrybuty rodowej zwierzchności nad ogółem wolnych współplemieńców: przejmował mund, czyli męską władzę opiekuńczą nad kobietą, która utraciła męskich krewnych uprawnionych do opieki; przejmował spadek po współplemieńcu, który zmarł, nie pozostawiając krewnych dostatecznie bliskich, by po nim dziedziczyć; występował w roli mściciela lub pretendenta do okupu 
za zemstę, jeżeli zabity został współplemieniec niemający krewnych uprawnionych do wróżdy wobec zabójcy ${ }^{1}$.

Pogańskie mity dynastyczne, a także mity początku plemienia kształtowały się przed progiem chrystianizacji i alfabetyzacji. Przekazywała je z pokolenia na pokolenie tradycja ustna. Wymogi chrześcijańskiej poprawności sprawiały, że zapisy tej tradycji lub bodaj wzmianki o niej pojawiały się w średniowiecznym piśmiennictwie bardzo rzadko, pod wpływem jakichś szczególnych okoliczności. Zapisy te i wzmianki wskazują jednak, że patriarchalny wzorzec krewniaczej opieki nad ludem dotyczył także sprawowanej za pośrednictwem króla lub bezpośrednio opieki ze strony pogańskich bóstw.

Reminiscencją takiego mitu jest wzmianka Bedy Czcigodnego o rodowodzie Hengista i Horsy, czyli dwóch braci, pod których przywództwem Anglosasi dokonali podboju Brytanii: „Byli oni synami Wiktigisla, którego ojcem był Witta, jego zaś ojcem był Woden, od którego wywodzą swój ród królowie wielu krain"2. Beda był zakonnikiem i jednym z najwybitniejszych intelektualistów chrześcijańskiej Europy VIII w. Musiał wiedzieć, że Woden (Wotan, Odyn) był czołowym bóstwem pogańskim świata germańskiego; a jednak bez mrugnięcia okiem oznajmił, że Woden był pradziadkiem Hengista i Horsy, którzy przywiedli lud Anglów z kontynentalnej Saksonii do nowej, wyspiarskiej ojczyzny. Wzmianka Bedy o wielu rodach królewskich, które wywodzą się od Wotana, dotyczy, jak się zdaje, także królestw germańskich z przeciwnej strony Kanału La Manche. Barbarzyński król był „wielkim krewniakiem” swojego ludu, więc boski protoplasta króla sprawował nadprzyrodzoną opiekę krewniaczą nad ogółem królewskich współplemieńców.

Tyle tylko, że nie wszystkie ludy barbarzyńskie miały królów. Jak zauważył Tacyt, u Germanów „wyzwoleńcy stoją niewiele wyżej od niewolników, z wyjątkiem jedynie ludów rządzonych władzą królewską, tam bowiem zdarza się, że wyzwoleńcy wyrastają i ponad wolnych, i ponad szlachetnie urodzonych"3. Aż do podboju Saksonii przez Karola Wielkiego plemiona saskie nie miały króla, tylko wodza powoływanego przez wielkoplemienny wiec w wojennej potrzebie. Nie było też w związku plemion saskich królów poszczególnych plemion. Hengist i Horsa nie

\footnotetext{
${ }^{1}$ K. Modzelewski, Barbarzyńska Europa, Warszawa 2004, s. 401-425.

2 „Erant autem filli Uictigisli, cuius pater Uitta, cuius pater Uoden, de cuius stirpe multarum prouinvinciarum reges originem ducunt Venerabilis", Beda der Ehrwürdige Kirchengeschichte des englischen Volkes, tłum. i wyd. G. Spitzbart, Darmstadt 1982, lib. I, cap. 15.

3 „exceptis iis gentibus quae regnantur”, P. Cornelius Tacitus, Germania, wyd. J. Kolendo, przekł. T. Płuciennik, Poznań 2008, cap. 25, s. 80 n.
} 
byli królami, tylko wodzami saskiego plemienia Anglów w zdobywczej wyprawie na Brytanię. Nie było też króla (po słowiańsku księcia, knęga) w związku plemion lucickich na początku XI w. ${ }^{4} \mathrm{Na}$ czele Longobardów, początkowo zwanych Winilami, nie stał u progu ich wędrówki żaden król, lecz - podobnie jak w wypadku Anglów, gdy ruszali z Saksonii na podbój Brytanii - dwaj wodzowie: bracia Ibor i Agio. Pierwszym królem Longobardów obrany został syn Agiona Agilmund; aż do karolińskiego podboju królestwo Longobardów nie było jednak monarchią dziedziczną, lecz elekcyjną. Każdego kolejnego króla obierano tam w obrzędzie orężnej aklamacji (potrząsanie włóczniami, gairething) na walnym wiecu longobardzkich wojowników. Zwykle nie był on synem poprzednika. Nie było w tym królestwie dynastii, nie mogło być zatem i dynastycznego mitu. Wspólnota polityczna monarchii Longobardów potrzebowała jednak mitu początku, który zapewniał jej spójność i gwarantował bezpośrednią opiekę krewniaczą bóstwa nad ludem. Mit taki został zapisany w pierwszym rozdziale tekstu Origo gentis Langobardorum. Przytaczam go we własnym dosłownym przekładzie:

Jest w północnych krainach wyspa, która nazywa się Skandanan [--], gdzie mieszka wiele ludów. Wśród nich był niewielki lud zwany Winilami. I była z nimi niewiasta imieniem Gambara, i miała dwóch synów: imię jednego Ibor, a imię drugiego Agio. Ci z matką swoją Gambarą dzierżyli przywództwo nad Winilami. Ruszyli się zatem wodzowie Wandalów, to jest Ambri i Assi z wojskiem swoim, i mówili do Winilów: „albo płaćcie nam dań, albo przygotujcie się do bitwy i bijcie się z nami". Wtedy odpowiedzieli Ibor i Agio z matką swoją Gambarą: „Lepiej nam przygotować się do bitwy niż płacić dań Wandalom". Wtedy Ambri i Assi, to jest wodzowie Wandalów, poprosili Wotana, aby dał im zwycięstwo nad Winilami. Odpowedział Wotan mówiąc: "Których pierwszych ujrzę o wschodzie słońca, tym dam zwycięstwo”. W tym samym czasie Gambara z dwoma swoimi synami, to jest Iborem i Agio, którzy byli wodzami Winilów, poprosili Freję, małżonkę Wotana, aby była przychylna Winilom. Wtedy Freja dała im radę, aby o wschodzie słońca przybyli Winilowie oraz ich żony z włosami rozpuszczonymi i ułożonymi wokół twarzy na podobieństwo bród i aby tak przybyły z mężami swoimi. Wtedy, gdy zabłysło wschodzące słońce, obróciła Freja, żona Wotana, łóżko, w którym spoczywał jej mąż, i skierowała jego twarz ku wschodowi, i zbudziła go. A on spoglądając ujrzał Winilów i ich kobiety z włosami rozpuszczonymi wokół twarzy i rzekł: „Kim są ci długobrodzi?”. I rzekła Freja do Wotana: „Tak jak dałeś im imię, daj im też zwycięstwo”. I dał im zwycięstwo,

4 "hiis autem omnibus qui communiter Liutici vocantur, dominus specialiter non presidet ullus", Kronika Thietmara, wyd. M.Z. Jedlicki, Poznań 1953, lib. VI, cap. 25, s. $349,351$. 
aby gdziekolwiek postanowią walczyć, zwyciężali. Od tej pory Winilowie zwani są Longobardami ${ }^{5}$.

Annalisa Bracciotti, której zawdzięczamy najnowszą i najlepszą edycję krytyczną Origo, jest zdania, że autor tego dziełka był pogańskim lub nostalgicznie przywiązanym do pogaństwa Longobardem („quasi certamente pagano o paganizzante"), jako że w tekście brak jakichkolwiek akcentów odwołujących się do chrześcijaństwa ${ }^{6}$. Uwaga ta dotyczy całego tekstu Origo gentis Langobardorum, więc także rozdziałów 2-7, które są krótką opowieścią o wędrówce Longobardów ze Skandynawii aż po Italię i o ich królach - poczynając od Agilmunda syna Agiona, aż po Grimoalda. Rozdział pierwszy, przedkrólewski, jest jednak czymś odrębnym i odmiennym: to saga, zapis pogańskiego mitu początków ludu. Skryba, który sporządził ten zapis, nie był jego autorem. Można raczej powiedzieć, że był tłumaczem, który tę sagę przełożył na łacinę i przeniósł na pergamin. Najłacniej mógł to uczynić jakiś ariański duchowny, jako że pod przykrywką ariaństwa dość długo trwały w monarchii Longobardów tradycje plemienno-pogańskie.

Przekład ten i zapis zostały dokonane bezpośrednio z ustnej tradycji. Prościutka łacina tekstu wykazuje charakterystyczne znamiona eposu przeznaczonego do ustnej recytacji. Ilekroć pojawiają się Ibor i Agio, towarzyszy im matka Gambara oraz informacja, że obaj bracia byli

5 „Est insula qui dicitur Scadanan, [-- ], ubi multae gentes habitant; inter quos erat gens parva quae Winnilis vocabatur. Et erat cum eis mulier nomine Gambara, habebatque duos filios, nomen uni Ybor et nomen alteri Agio; ipsi cum matre sua nomine Gambara principatum tenebant super Winniles. Moverunt se ergo duces Wandalorum, id est Ambri et Assi, cum exercitu suo, et dicebant ad Winniles: "Aut solvite nobis tributa, aut praeparate vos ad pugnam et pugnate nobiscum». Tunc responderunt Ybor et Agio cum matre sua Gambara: «Melius est nobis pugnam praeparare, quam Wandalis tributa persolvere». Tunc Ambri et Assi, hoc est duces Wandalorum, rogaverunt Godan, ut daret eis super Winniles victoriam. Respondit Godan dicens: «Quos sol surgente antea videro, ipsis dabo victoriam». Eo tempore Gambara cum duobus filiis suis, id est Ybor et Agio, qui principes erant super Winniles, rogaverunt Fream, uxorem Godan, ut ad Winniles esset propitia. Tunc Frea dedit consilium, ut sol surgente venirent Winniles et mulieres eorum crines solutae circa faciem in similitudinem barbae et cum viris suis venirent. Tunc luciscente sol dum surgeret, giravit Frea, uxor Godan, lectum ubi recumbebat vir eius, et fecit faciem eius contra orientem, et excitavit eum. Et ille aspiciens vidit Winniles et mulieres ipsorum habentes crines solutas circa faciem; et ait: «Qui sunt isti longibarbae?» Et dixit Frea ad Godan: «Sicut dedisti nomen, da illis et victoriam». Et dedit eis victoriam, ut ubi visum esset vindicarent se et victoriam haberent. Ab illo tempore Winnilis Langobardi vocati sunt", A. Bracciotti, Origo gentis Langobardorum. Introduzione, testo critico, commento, Roma 1998, s. 105-107, Biblioteca di cultura romanobarbarica, t. 2.

${ }^{6}$ A. Bracciotti, „Introduzione”, w: ibidem, s. 7. 
wodzami Winilów; także Ambri i Assi zawsze są określani jako wodzowie Wandalów. Powtórzenia te, podobnie jak charakterystyczny sposób relacjonowania dialogów miały ułatwić niepiśmiennemu słuchaczowi zapamiętanie informacji szczególnie ważnych, będących nośnikami ideowych treści mitu. Ustna tradycja nie głosiła morałów. Do świadomości odbiorców przemawiała fabuła.

Kluczowym ogniwem sagi o początku ludu Longobardów jest intryga Frei, w wyniku której Wotan na widok winilskich kobiet uczesanych na podobieństwo brodatych wojowników zakrzyknął: „Kim są ci długobrodzi?”. Sam Wotan tak wyglądał i nosił przydomek „długobrody”. Gdy Freja złapała go za słowo (nadałeś im imię, więc musisz im dać zwycięstwo, teraz i w przyszłości), Wotan nie mógł zaprzeczyć. Nadanie nazwy ludowi było tym, czym nadanie imienia dziecku: funkcją ojcowską. Tym sposobem Wotan stał się przybranym ojcem Winilów-Longobardów, zwłaszcza że nowa nazwa, którą im nadał, była jego własnym przydomkiem ${ }^{7}$. To był właśnie ideowy sens mitu: każdy wolny Longobard jest przybranym potomkiem germańskiego boga wojowników Wotana.

Gdy w 643 r. król Rotari kazał spisać z tradycji ustnej prawa Longobardów, nie zdecydował się umieścić w prologu pogańskiego mitu początku ludu. Sam był wprawdzie arianinem, ale tym bardziej nie mógł sobie pozwolić na to, by rzucić wyzwanie Kościołowi. Umieścił więc w prologu do edyktu praw tylko listę longobardzkich królów - od Agilmunda „z rodu Gugingów” (to, że był on synem Agiona, czyli wnukiem mitycznej Gambary, zostało przemilczane) aż po siebie samego. To jednak nie wystarczało ludowi. W drugiej połowie VII w. Longobardowie byli od dawna ochrzczeni i chrzcili swoje dzieci w kościołach, ale spis prawa, który nie informował, że każdy z nich jest przybranym potomkiem Wotana, nie miał w ich oczach należytej powagi. Dlatego w czasach króla Grimoalda, jakieś trzydzieści lat po Edykcie Rotariego, spisana została Origo gentis Langobardorum. Zachowała się ona w trzech rękopiśmiennych kodeksach, za każdym razem jako tekst poprzedzający Edykt Rotariego z jego oficjalnym prologiem, czyli listą królów. Nic dziwnego, że Paweł Diakon uważał Origo za właściwy prolog Edyktu, pochodzący od samego króla kodyfikatora ${ }^{8}$.

Losy rękopisów świadczą wymownie, że pogańska saga o początku ludu pozostawała ważnym elementem poczucia tożsamości chrześcijańskich

7 S. Gasparri, La cultura tradizionale dei Longobardi. Struttura tribale e resistenze pagane, Spoleto 1983, s. 12-16.

${ }^{8}$ Zob. na ten temat S. Gasparri, La memoria storica dei Longobardi, w: Le leggi dei Logobardi. Storia, memoria e diritto di un popolo germanico, wyd. C. Azzarra, S. Gasparri, Roma 2005, s. XXIV-XXVI. 
Longobardów pod panowaniem Grimoalda, a nawet jeszcze w czasach Karola Wielkiego. Nie mógł też pominąć jej w swej Historii Longobardów sam Paweł Diakon. Zrelacjonował on dość wiernie opowieść o Gambarze, Iborze i Agionie, Wotanie i Frei oraz przeistoczeniu Winilów w Longobardów, choć jako duchowny bywały na dworze Karola Wielkiego oddał co należne wymogom chrześcijańskiej poprawności; najpierw więc zdystansował się od tej opowieści, nazywając ją „śmieszną bajką", a na koniec, w związku ze zwycięstwem, które dał Wotan Winilom, dodał komentarz: „to wszystko jest śmiechu warte i trzeba to mieć za nic, dawanie zwycięstw nie leży bowiem w mocy ludzi, lecz raczej pochodzi z niebios". Ta próba sprowadzenia Wotana do rzędu zwykłych śmiertelników nie przeszkodziła Pawłowi Diakonowi w następnym zdaniu potraktować serio wywód o nadaniu Winilom nowej nazwy i objaśnić jej etymologię: „albowiem w ich języku lang znaczy długa, a bart - broda"9.

o długim trwaniu pogańskiego mitu początku świadczą także freski wymalowane na polecenie królowej Teodolindy w jej pałacu w Monzie. Freski te nie zachowały się, ale wiemy jak wyglądały dzięki opisowi Pawła Diakona: „golili sobie mianowicie wysoko karki, z przodu natomiast nosili długie włosy rozczesane na szczycie głowy na dwie strony i opadające aż do ust", tj. łączące się z brodą ${ }^{10}$. Nawiązanie do mitu o Frei, Wotanie i Winilach jest tu widoczne. Jeszcze u progu VII w. longobardzcy wojownicy strzygli się na podobieństwo boskiego praojca ludu. Zgodnie z przekonaniem zakorzenionym w kulturze europejskich barbarzyńców, adopcja była aktem magicznym, który stwarzał prawdziwe więzy krwi. Przybrane dzieci musiały być fizycznie podobne do przybranego ojca.

Trudno oprzeć się skojarzeniu opisu fresków w Monzie przez Pawła Diakona z opisem posągu Świętowita w Arkonie na Rugii przez Saksa Gramatyka ${ }^{11}$. Duńskiemu biskupowi Roskildy, który patrzył w twarz pogańskiego idola i kierował operacją jego obalenia ${ }^{12}$, mogło się wydawać, że

9 „ridicula fabula”, „haec risu digna sunt et pro nihilo habenda. Victoria enim non potestati est attribuita hominum, sed de caelo potius ministratur", Paolo Diacono, Storia dei Longobardi, wyd. L. Capo, Milano 1992, lib. I, cap. 8-9, s. 22-24.

10 „In qua pictura manifeste ostenditur, quomodo Langobardi eo tempore comam capitis tondebant [--]. Siquidem cervicem usque ad accipitium radentes nudabant, capillos a facie usque ad os dimissos habentes, quos in utramque partem in fronte discriminis dividebant", ibidem, lib. IV, cap. 22, s. 200.

11 „Corrasae barbae, crines attonsi figurabantur, ut artificis industriam Rugianorum ritum in cultu capitum aemulatam putares", Saxonis Gesta Danorum, wyd. J. Olrik, H. Ræder, Hauniae 1931, lib. XIV, cap. 39, 3, s. 372.

${ }^{12}$ W sprawie pochodzenia naocznych obserwacji obiektów kultu pogańskiego w Gesta Danorum, ks. XIV, lib. 39 zob. świetną, choć niestety nieopublikowaną pracę 
broda i fryzura Świętowita wyrzeźbione zostały na obraz i podobieństwo sposobu, w jaki strzygli się wszyscy Rugianie. W rzeczywistości kształtowanej przez mitologiczne wzory rzecz miała się raczej przeciwnie: to Rugianie starali się przez odpowiednie strzyżenie głów i bród upodobnić się do swojego boskiego praojca. Nie wiemy wprawdzie, czy Świętowit był przybranym, czy naturalnym przodkiem tego ludu, ale w oczach barbarzyńców wychodziło to na jedno.

Świętowit miał w ręce miecz, miał białego (żywego!) wierzchowca, na którym „walczył z nieprzyjaciółmi swojej boskości”, oraz sprawował obrzędy wyroczne w kwestii powodzenia (lub niepowodzenia) zamierzonych wypraw wojennych, był zatem bóstwem militarnym. W drugiej ręce trzymał jednak róg napełniony pitnym miodem, z którego w obrzędzie odprawianym po zbiorach kapłan Świętowita wróżył o urodzaju lub nieurodzaju w roku następnym. Podobnie jak Perun, którego Świętowit był prawdopodobnie lokalnym wcieleniem ${ }^{13}$, boski praojciec Rugian łączył więc przywództwo na wojnie z opieką nad gospodarstwem: żywił i bronił. Za obie te dziedziny odpowiadał (w dosłownym sensie) barbarzyński król. Rzymscy obserwatorzy wiedzieli o tym dobrze już w IV w. Ammianus Marcellinus zapisał, że u Burgundów „król nosi ogólną nazwę hendinos i zgodnie ze starym zwyczajem pozbawiany jest władzy, jeżeli pod jego rządami zachwieje się szczęście wojenne lub ziemia nie wyda obfitych plonów"14. Hendinos to przypuszczalnie przekręcony przez rzymskiego historyka starogermański termin keningaz, a zwyczaj usuwania króla w wypadku niepowodzenia wojennego lub nieurodzaju wynikał z przekonania, że król nie sprawdził się jako pośrednik między ludem a pogańskim sacrum o militarnych lub żywicielskich mocach. Mity dynastyczne przekonywały współplemieńców, że pod przywództwem rodu królewskiego spokrewnionego z bogami moce nadprzyrodzone zapewnią im zwycięstwa wojenne i wyżywienie. Wotan gwarantował ludowi Longobardów zwycięstwa. Freja była bóstwem trzeciej funkcji, a więc gwarantką obfitości. W obu zachodniosłowiańskich mitach dynastycznych - piastowskim i przemyślidzkim - czynne są moce nadprzyrodzone o żywicielskim charakterze.

magisterską Kacpra Malickiego „Chrzest Rugii 1168 r. Model chrystianizacji” (pod kierunkiem Jacka Banaszkiewicza), Warszawa 2000, wydruk w archiwum Instytutu Historycznego Uniwersytetu Warszawskiego.

13 A. Gieysztor, Mitologia Stowian, Warszawa 2006, s. 114 nn.

14 „generali nomine rex apellatur hendinos et ritu veteri potestate remouetur si sub eo fortuna titubauerit belli uel segetum copiam negauerit terra", Ammiani Marcellini Rerum gestarum libri qui supersunt, wyd. W. Seyfarth, Leipzig 1978, lib. XXVIII, s. 5, 14. 
Kronika Galla Anonima powstała w dramatycznych okolicznościach. Bolesław Krzywousty przywołał z wygnania swego starszego brata Zbigniewa, którego bezpośrednio po powrocie kazał oślepić, w wyniku czego Zbigniew zmarł. Konflikt dynastyczny został tym sposobem rozstrzygnięty, ale arcybiskup gnieźnieński Marcin - duchowy przywódca opozycji - obłożył Bolesława klątwą za bratobójstwo. Groziła detronizacja panującego, który po pozbyciu się brata był ostatnim żyjącym przedstawicielem rodu Piastów. Gall pisał Kronikę na dworze Bolesława Krzywoustego, gdzie był jednym z książęcych kapelanów. Zadeklarował on na wstępie Kroniki, że podjął się spisywania dziejów polskich królów i książąt z inicjatywy książęcego kanclerza Marcina, czyli na zamówienie monarszego dworu. Z naciskiem podkreślał, że Piastowie to „domini naturales”, przyrodzeni panowie Polski. Eksponowanie charyzmy tego rodu w obliczu zagrożenia należało do najważniejszych zadań propagandowych kronikarza. Nie można było przy tym pominąć pogańskiego mitu dynastycznego. Widocznie miał on w oczach grupy rządzącej wciąż wysoką wartość integrującą.

Fabularny wątek mitu ${ }^{15}$ przedstawia się następująco: W Gnieźnie książę Popiel przygotowuje „zwyczajem pogan” („more paganorum”) wielką ucztę na postrzyżyny swoich dwóch synów. Dwoma słowami „more paganorum” - Gall informuje czytelników kroniki (a byli to ludzie piśmienni, czyli duchowni, w znacznej części - podobnie jak i sam autor - cudzoziemcy), że postrzyżyny, wokół których osnuta jest akcja mitologicznej opowieści, są pogańskim rytuałem przejścia. Polegał on na obcięciu przez ojca dorastającemu synowi włosów i nadaniu imienia.

Zdarzyło się zaś z tajemnej woli Boga [„ex occulto Dei Consilio”], że przybyli tam dwaj goście [hospites, co oznacza wszelkich przybyszów, także cudzoziemców], którzy nie tylko że nie zostali zaproszeni na ucztę, lecz odpędzeni w krzywdzący sposób od wejścia do grodu. Zeszli więc na podgrodzie, gdzie trafili zupełnym przypadkiem [,forte fortuna"] przed domek oracza wspomnianego księcia [--]. Ów biedak, pełen współczucia, zaprosił tych przybyszów do swej chatki. A oni, [--] wchodząc do gościnnej chaty, rzekli mu: „Cieszcie się zaiste, żeśmy przybyli, a może nasze przybycie przyniesie wam obfitość dobra wszelkiego, a z potomstwa zaszczyt i sławę”.

15 Galli Anonymi Cronicae et gesta ducum sive principum Polonorum, wyd. K. Maleczyński, MPH sn., t. 2, Cracoviae 1952, lib. I, cap. 1-2, s. 9-11; przekład polski Anonim tzw. Gall. Kronika polska, tłum. i wyd. R. Grodecki, M. Plezia, Wrocław 1975, s. 11-14, z moimi modyfikacjami (dalej: Gall). 
Mieszkańcami gościnnego domu byli Piast syn Chościska i jego żona Rzepka; oboje oni z całego serca starali się zaspokoić wszelkie potrzeby gości [--]. Gdy przybysze zapytali, czy mają coś do picia, gościnny oracz odpowiedział: „Mam beczułkę dobrze sfermentowanego piwa, które przygotowałem na postrzyżyny jedynego syna, jakiego mam, lecz cóż znaczy taka odrobina? Wypijcie je, jeśli wola!”. Postanowił bowiem ów ubogi wieśniak w czasie, gdy książę jego pan będzie urządzał ucztę dla synów - bo kiedy indziej nie mógłby tego zrobić z powodu zbytniego ubóstwa - przyrządzić nieco lepszego jedzenia na postrzyżyny swojego malca i zaprosić paru równie ubogich przyjaciół nie na ucztę, lecz raczej na skromną zakąskę; toteż karmił prosiaka, którego przeznaczał na ową potrzebę.

W tym miejscu Gall przerywa wątek narracji, aby usprawiedliwić się z tego, co ma do napisania: „Dziwne rzeczy opowiem, lecz któż potrafi pojąć wielkie sprawy Boże? Albo któż poważy się zagłębiać w dociekania nad dobrodziejstwami Boga, który już w tym życiu niejednokrotnie wynosi pokorę biednych i wynagradza gościnność nawet u pogan?"16. Goście tedy każą spokojnie Piastowi nalewać piwo, bo dobrze wiedzą, że przez picie nie ubędzie go, lecz przybędzie. I podobno tak długo przybywało piwa, aż zapełniono nim wszystkie pożyczone naczynia, a naczynia biesiadników ucztujących u księcia okazały się puste. Polecają też zabić wspomnianego prosiaka, którego mięsem - rzecz nie do wiary - zapełniono dziesięć naczyń zwanych po słowiańsku cebrami. Piast i Rzepka tedy, na widok tych cudów, co się działy, przeczuwali w nich jakąś ważną wróżbę dla syna i już zamierzali zaprosić księcia i jego biesiadników, lecz nie śmieli, nie zapytawszy wpierw o to wędrowców. „«Po cóż zwlekać?» - za radą więc i zachętą gości [- -] książę i jego wszyscy współbiesiadnicy zaproszeni zostają do Piasta, a zaproszony książę wcale nie uważał sobie za ujmę zajść do swojego chłopa [--]. Skoro więc urządzono zwyczajową ucztę i pod dostatkiem przyrządzono wszystkiego, goście owi postrzygli chłopca i nadali mu imię Siemowita na wróżbę przyszłych losów"17.

Istotnie było to imię wróżebne. Siem (por. rosyjskie sem'â) oznaczało po słowiańsku rodzinę lub ród, a wit - tyle co pan lub panowanie, jak w boskich imionach Świętowita i Rugiewita. Imię nadane synowi Piasta

16 „Mira dicturus sum, sed quis valet Dei magnalia cogitare, vel quis audet de divinis beneficiis disputare; qui temporaliter pauperum humilitatem aliquociens exaltat et hospitalitatem eciam gentilium remunerare non recusat", Galli Anonymi Cronicae, cap. 2, s. 10.

17 „hospites illi puerum totonderunt, eique Semouith vocabulum ex presagio futurorum indiderunt", ibidem, cap. 2, s. 11; Gall, s. 14. 
przez dwóch tajemniczych przybyszów wskazywało, że ten chłopiec będzie założycielem rodu panującego. Zapowiedź się spełniła: gdy Siemowit dorósł i objawił swoje nadzwyczajne przymioty, „król królów i książę książąt”, czyli Bóg, „za powszechną zgodą ustanowił go księciem Polski, a Popiela wraz z potomstwem doszczętnie usunął z królestwa". Następuje opowieść o zagryzieniu Popiela przez myszy, po czym Gall odżegnuje się od pogańskich wątków mitu: „lecz dajmy spokój rozpamiętywaniu dziejów ludzi, których wspomnienie zaginęło w niepamięci wieków i których skaziły błędy i bałwochwalstwo" ${ }^{18}$. Kronikarz przyznaje się tu do czegoś, co w jego czasach dla benedyktyńskiego mnicha było raczej zasługą niż wstydem: że ocenzurował pogański mit.

Oprócz ingerencji cenzorskich, o których za chwilę, kronikarz czynił zadość wymogom chrześcijańskiej poprawności w ten sposób, że działanie pogańskiego sacrum przypisywał Bożej Opatrzności. Takie prowidencjalne deklaracje padają trzykrotnie: na początku i na końcu mitologicznej narracji oraz w jej punkcie kluczowym, gdy mowa o rozmnożeniu piwa i mięsa w chacie Piasta. Najpierw więc czytamy, że dwaj tajemniczy przybysze zjawili się u bram Gniezna w dniu wielkiej uczty postrzyżynowej synów Popiela „z tajemnej woli Boga”. Relację o działaniu mocy nadprzyrodzonych w chacie Piasta kronikarz poprzedza deklaracją, że musi opowiedzieć rzeczy dziwne, które jednak należy przypisać chrześcijańskiemu Bogu i nie dociekać Jego intencji. On bowiem może, gdy zechce, nagradzać cnoty już w życiu doczesnym i nie pozostawia gościnności bez nagrody „nawet u pogan”. Na koniec wreszcie to chrześcijański Bóg powołuje Siemowita do władzy książęcej, choć nie wiedzieć czemu robi to "za powszechną zgodą" ("concorditer”) ${ }^{19}$. Wreszcie wzmianka o „powszechnej zgodzie” przy wyniesieniu Siemowita na tron wydaje się nawiązaniem do rytuału aklamacji wiecowej, poprzedzanej zazwyczaj obrzędem wyroczni. Niewykluczone, że jest to reminiscencja oryginalnego brzmienia ustnej tradycji mitu.

W tym oryginalnym brzmieniu mitu sprawcą rozmnożenia piwa i wieprzowiny nie był rzecz jasna chrześcijański Bóg, lecz dwaj przybysze. Wiedzieli oni z góry, że wypitego przez nich piwa nie ubędzie, lecz przybędzie. Gdy się to stało, Piast i Rzepka uznali, że mają do czynienia z istotami dysponującymi mocą nadprzyrodzoną i nie śmieli zaprosić do swojej chaty, w której zagościła obfitość, księcia z biesiadnikami, zanim

18 „Sed istorum gesta, quorum memoriam oblivio vetustatis abolevit et quos error et ydolatria defedavit, memorare negligamus", Galli Anonymi Cronicae, cap. 3, s. 12.

19 Roman Michałowski, Restauratio Poloniae w ideologii dynastycznej Galla Anonima, PH 76, 1985, 3, s. 461, trafnie określił prowidencjonalne deklaracje Galla jako „komentarze odautorskie" do mitologicznej narracji, którą kronikarz relacjonuje. 
nie zapytali o zgodę swoich tajemniczych gości. Na koniec to owi goście właśnie postrzygli Siemowita i nadali mu „ex presagio futurorum” imię zapowiadające godność książęcą; prócz nadprzyrodzonej mocy rozmnażania napoju i jadła dysponowali zatem darem proroczym. Co więcej, dokonując wspólnie aktu postrzyżyn i nadając chłopcu imię nawiązali oni - podobnie jak Wotan wobec Longobardów - adopcyjne pokrewieństwo z założycielem dynastii piastowskiej i wszystkimi jego następcami. Nie ulega wątpliwości, że w fabularnej osnowie mitu owi dwaj przybysze byli postaciami absolutnie kluczowymi. Nie sposób wyobrazić sobie, by tradycja ustna nie zachowała ich imion. Przemilczenie ich tożsamości przez Galla interpretować zatem trzeba jako zabieg cenzorski, który pozwolił kronikarzowi przekazać mit dynastyczny bez popadania w „błąd bałwochwalstwa".

Kim byli w strukturze przedchrześcijańskiej mitologii Słowian owi dwaj goście, którzy w chacie Piasta okazali nadprzyrodzoną moc żywicielską, a przez obrzęd postrzyżyn i nadanie chłopcu imienia Siemowit zawarli więź adopcyjnego pokrewieństwa z pierwszym piastowskim księciem i całą dynastią jego następców? To, że u Galla są to postacie anonimowe wskazuje, że na początku XII w. nie dało się jeszcze zrobić z nich nosicieli chrześcijańskiego sacrum. Także mistrz Wincenty powtórzył opowieść Galla bez istotnych zmian. Dopiero w dwa stulecia po Gallu podjęto próbę chrystianizacji piastowskiego mitu założycielskiego. Widocznie przedchrześcijański nurt ustnej tradycji osłabł na tyle, że można było pokusić się o nadanie dwom gościom Piasta niebudzącej teologicznych zastrzeżeń tożsamości. U progu XIV w. Dzierzwa, powołując się na krążące - zapewne wśród duchowieństwa - opinie („fertur”), poinformował, że niektórzy uważają owych przybyszów za aniołów, inni zaś za świętych męczenników Jana i Pawła ${ }^{20}$. Naprawdę wiemy o nich tyle, ile napisał Gall. Ze słów kronikarza wynika, że zawsze działają oni i wypowiadają się we dwójkę. Razem przybywają do Gniezna, razem - odpędzeni od bram grodu - trafiają do chaty Piasta, razem zapewniają gospodarzy o materialnych korzyściach i przyszłej chwale potomka, będącej efektem ich przybycia, razem dokonują rozmnożenia piwa i mięsa oraz akceptują pomysł zaproszenia do chłopskiej chaty Popiela z biesiadnikami. Co najważniejsze, razem strzygą przyszłego władcę i nadają mu imię Siemowit. We wszystkim są nierozłączni jak bracia, rzec można: jak bliźniacy.

${ }^{20}$ Kronika Mierzwy, wyd. A. Bielowski, MPH, t. 2, Lwów 1872, s. 185-187. 
Wszystko to wywołuje nieodparte skojarzenie z boskimi bliźniakami indoirańskiej mitologii: braćmi Aświnami. W tradycji wedyjskiej występują oni w towarzystwie postaci kobiecej i wspólnie obdarzają ludzi obfitością. W mitologii rzymskiej odpowiednikiem Aświnów są dioskurowie Kastor i Polluks. Ich obecność w świecie germańskim jednoznacznie poświadcza Tacyt: „U Naharnawalów zobaczyć można gaj, miejsce starożytnego kultu, któremu przewodzi kapłan w kobiecym stroju; mówią, że bogami są tam - tłumacząc na kategorie rzymskie - Kastor i Polluks. Taki jest ich charakter, nazywają się Alci. Nie ma tam ani posągów, ani śladu obcego ceremoniału - czczą ich jednak jako braci i jako młodzieńców"21. Wreszcie Aleksander Gieysztor w poszukiwaniu słowiańskich dioskurów zwrócił uwagę na znalezisko archeologiczne: w 1969 r. podczas wykopalisk na wyspie Fischerinsel na jeziorze Tollensesee (a więc tam, gdzie lokalizuje się Radogoszcz) odkryto „posąg drewniany wysokości $178 \mathrm{~cm}$, złożony z dwu postaci zrośniętych głowami i tułowiem, datowany warstwami kulturowymi z XI i XII w. Jakiś kult dwu bliźniaczych bóstw, wprawdzie anonimowych, znalazł w ten sposób niespodziewane potwierdzenie"22. Z woli Anonima Galla bóstwa te muszą pozostać bezimienne, ale z narracji mitu dynastycznego Piastów wynika, że to one postrzygły Siemowita.

$\mathrm{Na}$ koniec wypada pokłonić się poprzednikom, których śladami podążałem: naszemu wspólnemu mistrzowi Aleksandrowi Gieysztorowi, Romanowi Michałowskiemu i Jackowi Banaszkiewiczowi. Ten ostatni, w świetnej rozprawie o piastowskim micie dynastycznym, był o krok od tej samej konkluzji, którą pozwoliłem sobie tu przedstawić. Napisał więc wprost, że Siemowitowi nadali imię „dwaj goście - bogowie”, co żadną miarą nie mieści się w kategoriach religii monoteistycznej, ale zawahał się i kilka stron dalej nazwał gości Piasta „bożymi wysłannikami”23. Wahanie można zrozumieć, zwłaszcza że Banaszkiewicz był pierwszym, który dotknął sedna.

21 „Apud Naharnavalos antiquae religionis lucum ostenditur. Praesidet sacerdos muliebri ornatu, sed deos interpretatione Romana Castorem Pollucemque memorant, ea vis numini,nomen Alcis. Nulla simulacra, nullum peregrinum superstitionis vestigium; ut fratres tamen, ut iuvenes venerantur", P. Cornelius Tacitus, op. cit., cap. 43, s. 94. Wątki dioskuryczne w pogańskich wierzeniach Germanów i Celtów tropili Georges Dumézil, Bogowie Germanów. Szkice o kształtowaniu się religii skandynawskiej, Warszawa 2006 (oryg. franc. 1959), zwłaszcza s. 32-35, oraz Steven O’Brien, Dioscuric Elements in Celtic and Germanic Mythology, „The Journal of Indo-European Studies” 1982, 10, s. 117-136.

22 A. Gieysztor, op. cit., s. 200.

${ }^{23}$ J. Banaszkiewicz, Podanie o Piaście i Popielu. Studium porównawcze nad wczesnośredniowiecznymi tradycjami dynastycznymi, Warszawa 1986, s. 143 i 149. 


\section{Streszczenie}

Pogańskie mity początku barbarzyńskich ludów średniowiecznej Europy wywodziły rodowód pierwszego króla (a jeśli lud u swego zarania nie miał króla - to całego ludu) od boskiego praojca i opiekuna. Według Bedy Hengist i Horsa - dwaj bracia, pod wodzą których Anglowie podbili Brytanię - byli prawnukami Odyna. Beda dodał, że od Odyna wywodzi się wiele rodów królewskich. Origo gentis Langobardorum głosiła, że w wyniku intrygi Frei Odyn nadał ludowi Winilów nową nazwę Longobardów, przez co ich mimowolnie usynowił i winien był im odtąd ojcowską opiekę. Na tym tle Autor rozpatruje zapisany na początku XII w. mit dynastyczny Piastów. Nosicielem treści ideowych mitu była jak zwykle w takich razach, fabuła. Głosiła ona, że w Gnieźnie przygotowywano równocześnie dwie uroczystości postrzyżyn, czyli pogańskiego rytuału przejścia, podczas którego ojciec obcinał dorastającemu synowi włosy i nadawał mu imię. Książę Popiel przygotowywał w grodzie ucztę z okazji postrzyżyn swoich dwóch potomków, a ubogi oracz Piast w swojej chacie gotował skromną uroczystość na postrzyżyny jedynaka. Na ucztę książęcą przybyli do grodu dwaj tajemniczy wędrowcy, ale ich odpędzono od bramy. Trafili oni do chaty Piasta, gdzie gospodarz podał im całe piwo i wieprzowinę, które przygotował na postrzyżyny swego syna. Goście wiedzieli z góry, że podanego im napoju i jadła nie ubędzie, lecz przybędzie; rzeczywiście nastąpiło cudowne rozmnożenie wieprzowiny i piwa, którego w tym samym czasie zabrakło na uczcie u księcia. Za pozwoleniem wędrowców zaproszono księcia z biesiadnikami do chaty Piasta, po czym przybysze (a nie ojciec!) postrzygli syna Piasta i nadali mu „ex presagio futurorum" imię Siemowit (siem - rodzina, ród, wit - panowanie). Gdy chłopiec podrósł, z woli Bożej został okrzyknięty księciem i dał początek dynastii Piastów.

W fabularnym wątku tej opowieści dwaj tajemniczy wędrowcy dysponują nadprzyrodzoną mocą rozmnażania jadła i napoju oraz darem wróżebnym i przyjmują wobec młodzieńczego Siemowita rolę ojcowską, czyli adoptują go; odgrywają zatem absolutnie kluczową rolę. Z woli kronikarza pozostają oni jednak postaciami anonimowymi. Kronikarz przyznał się, że pominął szczegóły „skażone błędem bałwochwalstwa". Porównawcza analiza religioznawcza prowadzi Autora do wniosku, że rolę przybranych ojców pierwszego piastowskiego władcy odegrali w micie założycielskim państwa polskiego dwaj boscy bracia, darzący ludzi obfitością, czyli odpowiednicy bliźniąt Aświnów w mitologii indoirańskiej lub rzymskich dioskurów, których Tacyt dostrzegł także w kulcie pogańskim starożytnych Germanów.

\section{Who Did the Ritual Cutting of Siemowit's Hair? Slavonic Dioscuri in the Dynastic Myth of the Piasts}

Pagan myths of origins of barbarian peoples in medieval Europe traced the descent of the first ruler (or, if there was no king at that time, of the whole people) from the divine forefather and guardian. According to Saint Bede the Venerable, Hengist and Horsa - the two brothers and legendary leaders of the first Anglo-Saxon settlers in Britain - were Odin's grandsons. Bede said that Odin was an ancestral 
figure of many royal dynasties. The Origo gentis Langobardorum claimed that, as a result of Frea's intrigue, Odin gave a new name to the Winnili people, calling them Lombards, and through this act he took them under his special care. It is in this context that the author analyses the dynastic myth of the Piasts written down in the twelfth century. The carrier of ideology here was, as usually in such cases, the fable. According to it, in the town of Gniezno two feasts were being prepared on the occasion of the coming of age ceremony, during which a father cut his son's hair and gave him a name. Prince Popiel, who resided in the town, was preparing a feast for his two sons, and at the same time the poor ploughman Piast in his hut was getting ready for his son's feast. It was at that time that two mysterious wanderers arrived in the town, but instead of being invited by Popiel, they were turned away from his gates. So they went to Piast's hut where they were treated hospitably to beer and pork, reserved by Piast for the guests he had invited to the celebration. The wanderers new that the drink and food would not run out, on the contrary it would miraculously multiply, and this indeed happened, while at the same time Prince Popiel run out of food and drink. On the advice of the strangers, the prince with his guests were invited to Piast's hut, and then the wanderers (and not the father!) performed the ceremony of cutting Piast's son's hair and "ex presagio futurorum" - in presage of the future - gave him the name of Siemowit (siem meaning family, or clan; and wit - ruling, or mastering). When the boy grew up, by God's will he was made prince and became the ancestor of the Piast dynasty.

In the fictional plot of the story two mysterious wanderers had a supernatural power to multiply food and drink, and to foresee the future; they took on the role of father to young Siemowit - thus they played the fundamental role in the plot. But on the chronicler's will they remain anonymous. The chronicler admitted that he had omitted details "that were contaminated by the faults of idolatry". A comparative religious analysis has led the author to the conclusion that the role of guardians of the first Piast ruler in the myth of the early origins of the Polish state was played by the divine twin brothers, who brought abundance to people, i.e. the counterpart of the Ashvins in Hindu mythology, or the Dioscuri in Roman and Greek mythologies, seen by Tacitus also in the pagan cult of the ancient Germans.

Translated by Grażyna Waluga

\section{Bibliografia}

Anonim tzw. Gall. Kronika polska, tłum. i wyd. Roman Grodecki, Marian Plezia, Ossolineum, Wrocław 1975, Biblioteka Narodowa seria 1.

Ammiani Marcellini Rerum gestarum libri qui supersunt, wyd. Wolfgang Seyfarth, Teubner, Leipzig 1978, Bibliotheca Scriptorum Graecorum et Romanorum Teubneriana.

Beda der Ehrwürdige Kirchengeschichte des englischen Volkes, tłum. i wyd. Günter Spitzbart, Wissenschaftliche Buchgesellschaft, Darmstadt 1982.

Banaszkiewicz Jacek, Podanie o Piaście i Popielu. Studium porównawcze nad wczesnośredniowiecznymi tradycjami dynastycznymi, PWN, Warszawa 1986. 
Bracciotti Annalisa, Origo gentis Langobardorum. Introduzione, testo critico, commento, Herder, Roma 1998, Biblioteca di cultura romanobarbarica, t. 2.

Dumézil Georges, Bogowie Germanów. Szkice o kształtowaniu się religii skandynawskiej, Oficyna Naukowa, Warszawa 2006.

Galli Anonymi Cronicae et gesta ducum sive principum Polonorum, wyd. Kazimierz Maleczyński, MPH sn., t. 2, Cracoviae 1952.

Gasparri Stefano, La cultura tradizionale dei Longobardi. Struttura tribale e resistenze pagane, Fondazione CISAM, Spoleto 1983.

Gasparri Stefano, La memoria storica dei Longobardi, w: Le leggi dei Logobardi. Storia, memoria e diritto di un popolo germanico, red. Claudio Azzarra, Stefano Gasparri, Viella, Roma 2005, s. XVII-XL, Altomedioevo, t. 4.

Gieysztor Aleksander, Mitologia Słowian, wstęp Karol Modzelewski, Wydawnictwo Uniwersytetu Warszawskiego, Warszawa 2006.

Kronika Mierzwy, wyd. August Bielowski, MPH t. 2, Lwów 1872.

Kronika Thietmara, tłum. i wyd. Marian Z. Jedlicki, Instytut Zachodni, Poznań 1953, Biblioteka Tekstów Historycznych, t. 3.

Malicki Kacper, „Chrzest Rugii 1168 r. Model chrystianizacji”, Warszawa 2000 (wydruk, archiwum Instytutu Historycznego Uniwersytetu Warszawskiego).

Michałowski Roman, Restauratio Poloniae w ideologii dynastycznej Galla Anonima, PH 76, 1985, 3, s. 457-480.

Modzelewski Karol, Barbarzyńska Europa, Iskry, Warszawa 2004.

O'Brien Steven, Dioscuric Elements in Celtic and Germanic Mythology, „The Journal of Indo-European Studies" 1982, 10, s. 117-136.

Paolo Diacono, Storia dei Longobardi, wyd. Lidia Capo, Mondadori, Milano 1992, Scrittori greci e latini.

P. Cornelius Tacitus, Germania, wyd. Jerzy Kolendo, tłum. Tomasz Płuciennik, Wydawnictwo Naukowe Uniwersytetu im. Adama Mickiewicza, Poznań 2008, Fontes Historiae Antiquae, z. 10.

Saxonis Gesta Danorum, wyd. Jørgen Olrik, Hans Ræder, Levin \& Munkesgaard, Hauniae 1931.

Biogram: Karol Modzelewski - historyk mediewista, członek rzeczywisty Polskiej Akademii Nauk, professor emeritus Uniwersytetu Warszawskiego; zajmuje się Europą barbarzyńską, wędrówkami ludów, początkami państw słowiańskich, w tym państwa Piastów. 